\title{
Analysis of the Countermeasures for Expanding the Education Scale of Foreign Students in Chinese Colleges and Universities in Jilin Province
}

\author{
Xin Cheng, Yang Lin
}

Jilin Agricultural University, Changchun, Jilin, China, 130118

\begin{abstract}
Keywords: Colleges and Universities in Jilin Province, International Students in China, the Education Scale
\end{abstract}

\begin{abstract}
Jilin Province has attached great importance to the education of foreign students in recent years. The number of students studying in China has increased year by year. After some achievements have been made, we have also seen some problems in the education of students studying in China. In this paper, and the country and other elements to analyze the lack of education in Jilin Province, and put forward the measures to expand the scale of education of foreign students in the province.
\end{abstract}

\section{The Education Status Quo of Foreign College Students in Jilin Province}

Since the founding of higher education in Jilin Province, especially since the reform and opening up, has made remarkable achievements, but also shows a lot of unavoidable problems, such as the slow process of internationalization of higher education, international education is an important symbol of international education. From Figure 1 we can see from 2010 to 2014, the number of students in Jilin Province, the total number of slow growth, which also has a decreasing trend. But the total number of graduate students studying in China showed an increasing trend. The total number of graduate students in the total number of students is from 2010 to $15.7 \%$ in 2014 to $18.4 \%$, showing the momentum of development.

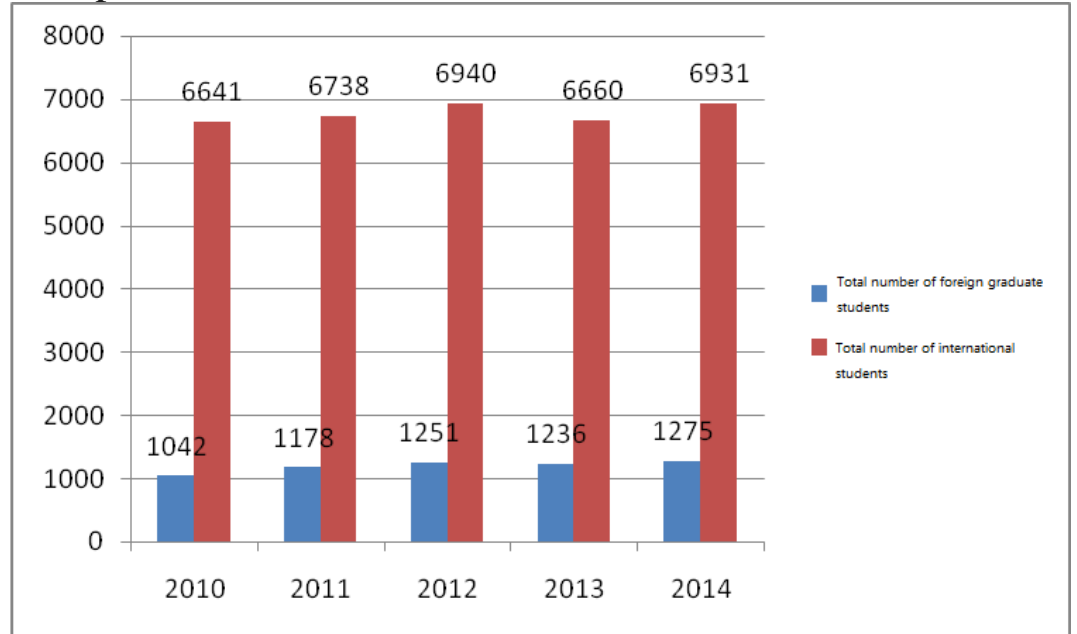

Source: According to the "China Student Management Information System" finishing

Figure 1 Number of students studying in Jilin Province from 2010 to 2014 (unit: person)

Jilin province student education presents the following characteristics:

Students in China between the universities are not balanced. Most of the students concentrated in a small number of subordinate institutions, Jilin University, Northeast Normal University is the largest number of students in Jilin Province to receive two schools. According to the 2010 statistics in 2014, the total number of students in these two universities accounted for half of the total number of students in the province, the past few years the total number of small changes, accounting for the proportion of the total number of students in the province declined from 57\% To 50\% in 2014, but it is still the primary choice for students to study in Jilin Province.

Students to Asian countries based. At present, foreign students from Jilin Province mainly come 
from Asian countries. In 2014, the number of Asian students is 4689, accounting for $67.7 \%$ of the total number of students studying in China. South Korean students accounted for nearly half of the total number of students in Jilin Province.

Students from Neighboring countries are more. At present, the proportion of Korean students in Jilin Province is the highest. According to the country, the number of students in Jilin Province is 2655 in 2004, 933 in Russia, 433 in India, 257 in Mongolia and 254 in Japan. The first two of the South Korean and Russian students accounted for $56 \%$ of the total annual total. It can be seen that the source of students in the province is mainly neighboring countries.

Profession is mainly literature and medicine. In 2014, Jilin Province, China students to study literature has 4034 people, medical has 1035 people, accounting for $58.2 \%$ of the total number of students and $14.9 \%$. The number of agronomy is small, only $0.5 \%$. as shown in picture 2 :

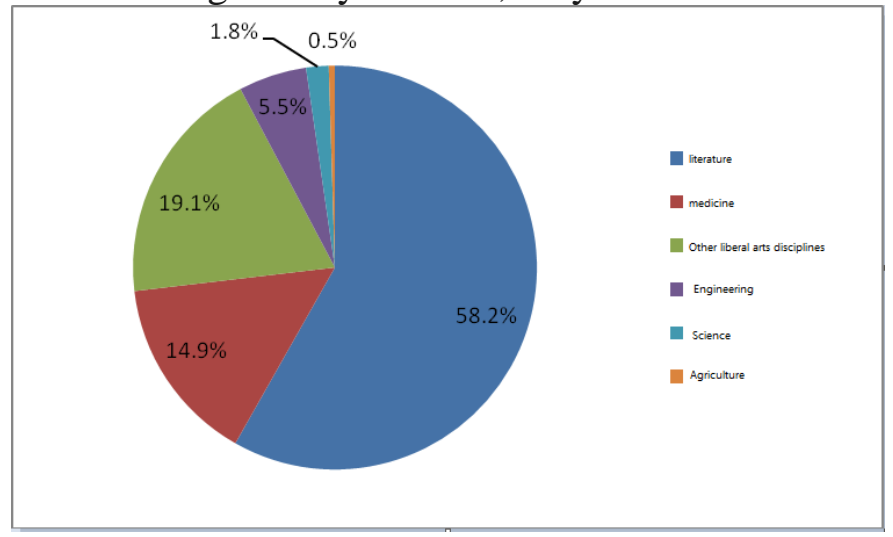

Source: According to the "China Student Management Information System" finishing

Figure 2 2014, Jilin Province, college students studying professional statistics

Jilin Province, China students, the higher number of students

Between 2010 and 2014, the number of students in the calendar year was higher than that of the non-diploma students, and the proportion of the total number of students with the total number of students was gradually increasing. The proportion of non-diploma was declining.

\begin{tabular}{|c|c|c|c|}
\hline Year & $\begin{array}{l}\text { Education } \\
\text { student }\end{array}$ & $\begin{array}{l}\text { total } \\
\text { people }\end{array}$ & $\begin{array}{l}\text { The proportion of } \\
\text { education students }\end{array}$ \\
\hline 2014 & 3745 & 6931 & $54.0 \%$ \\
\hline 2013 & 3227 & 6660 & $48.5 \%$ \\
\hline 2012 & 3584 & 6940 & $51.6 \%$ \\
\hline 2010 & 3465 & 6738 & $51.4 \%$ \\
\hline
\end{tabular}

Source: According to the "China Student Management Information System" finishing

Figure 3 2010-2014 Jilin Province, the number of students studying in the number of students

Jilin Province, the development of foreign students' education is relatively slow, there are some problems in the enrollment and education of foreign students, the distribution of students in colleges and universities is not balanced, students are too concentrated source countries, students choose a single professional, did not play the province's academic advantages

\section{The Problems Existing in the Education of Foreign College Students in Jilin Province}

Provincial Institutions Have No Advantage in Enrollment. According to the above data analysis, Jilin province student education mainly concentrated in Jilin University, Northeast Normal University, the two subordinate institutions. The number of students enrolled in the two institutions 
accounts for more than $50 \%$ of the total number of students studying in the province. These two subordinate institutions have their own characteristics, in the teachers and hardware facilities is superior to other provincial institutions, but not to say that other provincial institutions are not competitive, on the contrary, some provincial institutions have a long history. There are many international level key disciplines, each with its own characteristics, in the current domestic undergraduate and even graduate students have made great achievements. Such as Yanbian University is a family with a certain characteristics of a comprehensive university, but also the national "211" project key construction university; Changchun University of Science and Technology, its optical engineering is a national key disciplines, optical and optical engineers is the key disciplines of the National Defense Science and Technology Commission Jilin Agricultural University, as the only key high agricultural institutions in Jilin Province, it has a national research platform and a number of ministries and commissions at the level of scientific research platform, in the agricultural disciplines unique Characteristics; Changchun University of Traditional Chinese Medicine as the only focus of the province of traditional Chinese medicine University, which medicine, traditional Chinese medicine in the two disciplines in the national rankings are also among the forefront, and the development of a subsidiary hospital as a student practice base. In addition, the Northeast Electric Power University, Jilin University of Finance and Economics, North China University also have their own school advantage. However, the provincial colleges and universities in the recruitment of students did not form to play their own advantages, and other institutions complement each other good and bad trend.

\begin{tabular}{|c|c|c|c|c|c|c|c|c|}
\hline & $\begin{array}{l}2011 \\
\text { Number } \\
\text { of } \\
\text { people }\end{array}$ & ratio & $\begin{array}{l}2012 \\
\text { Number } \\
\text { of people }\end{array}$ & ratio & $\begin{array}{l}2013 \\
\text { Number of } \\
\text { people }\end{array}$ & ratio & $\begin{array}{l}2014 \\
\text { Number } \\
\text { of people }\end{array}$ & ratio \\
\hline $\begin{array}{l}\text { Yanbian } \\
\text { University } \\
\text { Changchun } \\
\text { University } \\
\text { of Science } \\
\text { and } \\
\text { Technology }\end{array}$ & 318 & $12.4 \%$ & 395 & $12.7 \%$ & 349 & $12.5 \%$ & 296 & $12.3 \%$ \\
\hline $\begin{array}{l}\text { Jilin } \\
\text { Agricultural } \\
\text { University } \\
\text { Chinese } \\
\text { Journal of } \\
\text { Traditional }\end{array}$ & 22 & $0.3 \%$ & 57 & $0.8 \%$ & 29 & $0.4 \%$ & 39 & $0.6 \%$ \\
\hline $\begin{array}{l}\text { Chinese } \\
\text { Medicine } \\
\text { and } \\
\text { Pharmacy }\end{array}$ & 124 & $1.8 \%$ & 87 & $1.3 \%$ & 74 & $1.1 \%$ & 71 & $1.0 \%$ \\
\hline $\begin{array}{l}\text { North China } \\
\text { University }\end{array}$ & 655 & $9.7 \%$ & 771 & $11.1 \%$ & 725 & $10.9 \%$ & 898 & $13.0 \%$ \\
\hline Total & 1957 & $29.0 \%$ & 2189 & $31.5 \%$ & 2010 & $30.2 \%$ & 2155 & $31.1 \%$ \\
\hline
\end{tabular}

Source: According to the "China Student Management Information System" finishing

Figure 4 Jilin Province, some key provincial colleges and universities over the years enrollment statistics

The International and International Sources of Students Are Seriously Imbalanced. European countries, but according to the country, the European countries of the students to Russian students mainly, of which the Asian continent part of the Russian students mainly. Africa is also an important part of the students' students in Jilin Province, which is related to Chinese aid policy and 
the distribution of scholarships. Oceania and the number of students in the United States in our province is small and little change in the year, the reason worthy of our in-depth thinking. The number of foreign students in neighboring countries is relatively obvious in the country, but the imbalance of students in Jilin Province is particularly prominent, as in the previous statistics, South Korea and Russia accounted for more than half of the total number of students in Jilin Province. This shows that we need to go abroad in the enrollment and publicity needs of the country, to new areas, explore new ways.

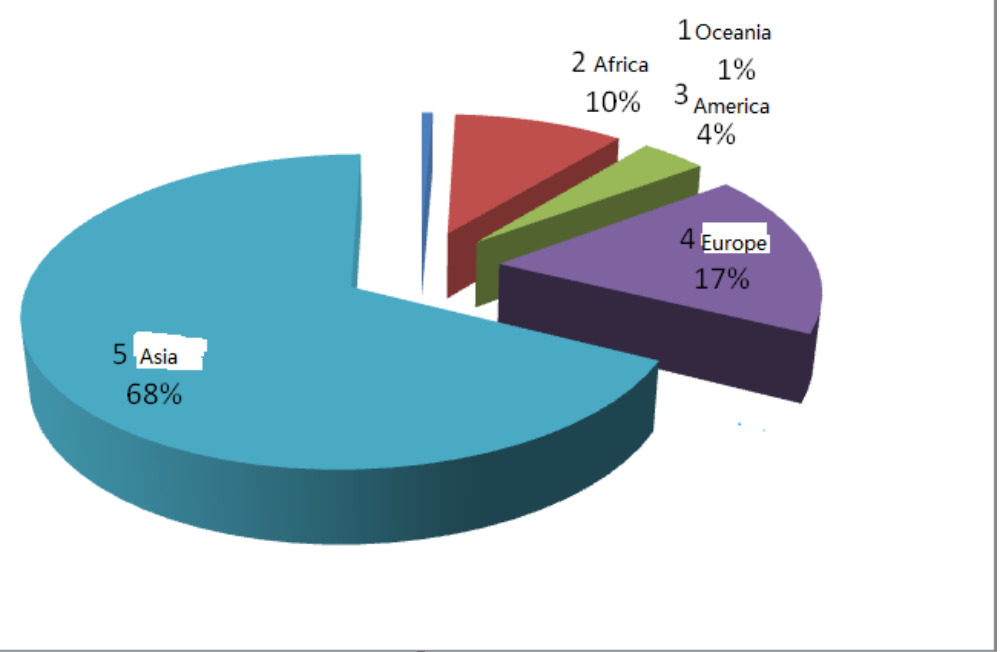

Source: According to the "China Student Management Information System" finishing

Figure 5 Statistics of Intercontinental Distribution of Students in Jilin Province

The Overall Scale of the Students Is Low and the Growth Is Slow. The total number of students in Jilin Province in the proportion of students in China is not high. Whether from the scale or from the growth rate, Jilin Province, colleges and universities are generally in a relatively low position. Jilin Province is located in the hinterland of the Northeast and the climate is cold, long winter, which have affected the choice of students. In addition, from the quality of education, Jilin Province in the education of students needs to strengthen. From the learning environment and other hardware conditions, the economic level of Jilin Province is relatively backward, students learning and living environment also needs to be improved.

The Enrollment Is Too Dependent on Government Scholarships from the Source of Funding. Some of the universities in China are mainly dependent on the government scholarships or other types of scholarships and the proportion of self-financed students is low. From the data of 2014, the Northeast Normal University students 483 people, the total number of students in the year 1165 people, public students accounted for 41.5\%; Changchun University of Science and Technology students born 181 people, a total of 296 people, accounting students accounted for $61.1 \%$ The number of students more than half. Other institutions also exist in the proportion of public expense and self-paid students unreasonable phenomenon.

The Level of Students Is Low. In 2014, Jilin Province, 3745 students of secondary school students, 3186 non-academic students and education accounted for $54 \%$ of the total number of students. As mentioned above, $58.2 \%$ of the students choose to study literature, of which $26.5 \%$ of the secondary school students, non-diploma accounted for $73.5 \%$, which means that a large part of the students in China is a language, The main purpose is to carry out language training, which also shows that the number of students with good Chinese proficiency before coming to China is very small, and the low level of Chinese language in China has affected their professional choice.

\section{The Recommendations for Developing Foreign Students Education of Jilin Province in China}

Increase Enrollment Propaganda and Enhance the International Influence of Colleges and Universities. To play the role of the Confucius Institute, not only through the Confucius Institute for Chinese and Chinese culture propaganda, but also through the Confucius Institute to develop a 
certain Chinese language based on foreign students, so that in China to choose professional diversification. Confucius Institute is also a way for foreign students to understand China, to the Confucius Institute to send outstanding domestic teachers to give lectures, show the province's teachers, so that students learn about the development of education in our province, so as to study in Jilin Province, interest and confidence.

"China is able to help us better promote international exchanges, is the cultural transmission between countries and even between countries of political contact" matchmaker "or" bridge. "[1] Actively develop international exchanges, increase Inter-school visits and public school teachers to go abroad to learn the international elite school approach, through international exchanges and universities around the world to establish friendly relations and promote student exchanges, so as to introduce quality students resources. Through the teacher research and foreign university teachers, research institutes to establish contact to encourage students to study in China.

The province of inter-university exchange between the sharing of international resources to share the experience and success of international students enrollment in the admissions of students on the pros and cons, to play each university's own advantages, strengths and weaknesses, training high-quality students.

Open up various forms of funding channels and increase the enrollment of public students. Continue to play the Chinese government scholarship enrollment advantages, and through government scholarships to recruit higher levels of students. Encourage Chinese well-known enterprises to set up scholarship projects to study in China, increase the local government scholarship investment efforts. Set up school scholarships for some students to provide opportunities for school learning, while improving school influence and visibility.

Recruit and Train Students according to School Characteristics. Jilin Province, a lot of colleges and universities, the general development of student education is relatively slow, colleges and universities should be based on their own school resources, play their own advantages, to encourage students to learn the strengths of the school discipline. Will be the best teaching resources, teachers apply to the training of students. The distribution of students in our province is too concentrated, mainly in the national subordinate institutions in school and this pattern also restricts the province of foreign students to expand the scale of education. While continuing to play the advantages of subordinate institutions at the same time should also allow other provincial institutions, according to the specific institutions of the disciplines and professional characteristics of joint enrollment, institutions between the needs of students can be recommended to other institutions, or to take the model of joint training, the formation of complementary advantages to China students education model.

Provincial colleges and universities have a unique subject of professional and these characteristics can attract foreign students. Such as Chinese students interested in Chinese medicine, Chinese language and literature and other professional, the global context of keen on economics, management and other professional, developing countries preferred students of engineering and agronomy. These specialties are certain disciplines of certain colleges and universities in Jilin Province. As long as we enroll students in the province, we can integrate the common resources of colleges and universities in the province, the strengths of various colleges and universities to play out, it is not difficult to meet the diverse needs of students studying abroad, so as to let the characteristics of colleges and universities in their own areas of expertise to expand the scale of students.

Improve the Quality of Teaching Students. "Expanding the Scale of Students in China" and 'Optimizing Educational Structure' for the coming of our overseas students, 'expanding the scale' is the primary and core task for the next ten years. 'Optimizing the structure' is a proposition that needs to be kept in mind. [2] Of course, the "scale" does not mean equivalent to enlarge the existing number of students, the scale of the expansion at the same time to achieve "optimize the structure." "Optimization structure" compared with the original "raise the level", the connotation is more profound and comprehensive, but also more in line with the essence of scientific development. This is to remind us that when we expand the scale of international students, do not forget to pay 
attention to the quality of teaching students.

Chinese foreign student education is not as strong as the education of foreign students in developed countries as a strong attraction, Jilin Province from the economic, geographical, climate and these aspects do not have the advantage. So in the pursuit of the quality of education, we must pay attention to it. First of all, for different levels of international students to develop a suitable training program cannot copy the application of Chinese students training program, training institutions should take the time to study the developed countries to develop students in the model, learn from their experience in training students. Finally, according to the actual situation of foreign students, to develop suitable for their own professional, reasonable and practical training programs for students to cultivate a real talent, which also improve the university's visibility.

In the optimization of teaching at the same time, we should also pay attention to cultivate high-level students, to increase the enrollment of graduate students, to study in China must come to China before the professional undergraduate study, the higher level of entry, or doctoral degree, the learning initiative is high, halfway drop out the possibility of small, able to seriously do research, teacher training is more willing to choose such a high level of students. It is an effective way to improve the quality of teaching by increasing the enrollment of graduate students and thus raising the overall structure of the international students.

Improve the University's Own Infrastructure and Urban Construction. The construction of colleges and universities should first be the construction of teachers, colleges and universities in the introduction of talent should pay attention to the overseas study of the absorption of talent, which is an important step in the province of internationalization. Teachers who have experience in studying abroad can apply the educational model of foreign developed countries in practical teaching, and their foreign language level is higher than that of ordinary college teachers. They will become potential students to cultivate students. The introduction of the same time also encourage the school teachers to study abroad, so that more teachers to go out to change its backward educational philosophy, education and teaching breakthrough and innovation. Only have a strong team of teachers, in order to expand the scale of international students, improve the level of training students to do a good job.

Followed by the construction of university hardware facilities, including international students accommodation, catering and learning environment. Students studying in China, the campus and the dormitory are their only home, how this home environment will also affect the state of students studying, and even decided to stay or go abroad. Compared to Chinese students in the collective dormitory, students are more inclined to have independent private space. Jilin Province should increase the capital investment of infrastructure, for the basic living space for students to protect. Some students in Jilin Province have religious beliefs, they have different requirements in the custom, college administrators and teachers should respect their beliefs to help them complete the religious needs. At the same time, Muslim students should set up separate catering facilities for them. We have to encourage Chinese students to help them. Some colleges and universities are equipped with students, and are worthy of study in colleges and universities.

Finally, we should strengthen the infrastructure construction of major cities in the province. Changchun, for example, students dissatisfied with the city is very high, such as students generally reflect the city traffic congestion, traffic is not developed, the public environment is poor. A city's infrastructure is a city's face, improve the environment of public places, etc. can not only leave a good impression for students, but also for our country and even our country played a positive publicity.

\section{Acknowledgements}

Fund Project: This article is 2017 years Jilin Province Department of Education "thirteen five" social science research planning project: the Chinese and foreign students cultural conflict and integration research under the background of internationalization education - taking Jilin University as an example (project number: JJKH20170325SK). 
2017 Jilin Provincial Education Department, the stage research result of "13th Five-Year Plan" Social Science Research Project: Jilin Province China students' scholarship project management status and countermeasures research (project number: JJKH20170331SK).

\section{References}

[1] Jiang Guohua. Sun Cheng. Study abroad in China: an industry that has yet to be valued and developed [J]. Higher Education Research, 1999 (6)

[2] Wang Yong. "Expand the scale of students in China" and "optimize the educational structure" [N]. People's Network, 2010-9-17 